\title{
High resolution melting assay as a reliable method for diagnosing drug-resistant TB cases: a systematic review and meta-analysis
}

\author{
Masoud Keikha ${ }^{1,2}$ and Mohsen Karbalae ${ }^{3^{*}}$
}

\begin{abstract}
Background: Tuberculosis (TB) is one of the most contagious infectious diseases worldwide. Currently, drug-resistant Mycobacterium tuberculosis (Mtb) isolates are considered as one of the main challenges in the global TB control strategy. Rapid detection of resistant strains effectively reduces morbidity and mortality of world's population. Although both culture and conventional antibiotic susceptibility testing are time-consuming, recent studies have shown that high resolution melting (HRM) assay can be used to determine the types of antibiotic resistance. In the present metaanalysis, we evaluated the discriminative power of HRM in detecting all drug-resistance cases of TB.

Methods: A systematic search was performed using databases such as Cochrane Library, Scopus, PubMed, Web of Science, and Google Scholar. Related studies on the effect of HRM in the diagnosis of drug-resistant (DR) TB cases were retrieved by April 2021. We used Meta-Disc software to evaluate the pooled diagnostic sensitivity and specificity of HRM for the detection of each type of drug-resistant cases. Finally, diagnostic value of HRM was characterized by summary receiver operating characteristic (SROC) curve and the area under the curve (AUC) method.

Results: Overall 47 studies (4,732 Mtb isolates) met our criteria and were included in the present meta-analysis. Sensitivity, specificity, and AUC of HRM were measured for antibiotics such as isoniazid $(93 \%, 98 \%, 0.987)$, rifampin (94\%, $97 \%$, 0963), ethambutol $(82 \%, 87 \%, 0.728)$, streptomycin (82\%, 95\%, 0.957), pyrazinamide (72\%, 84\%, 0.845), fluoroquinolones (86\%, 99\%, 0.997), MDR-TB (90\%, 98\%, 0.989), and pan-drug-resistant TB (89\%, 95\%, 0.973).

Conclusions: The HRM assay has high accuracy for the identification of drug-resistant TB, particularly firs-line anti-TB drugs. Therefore, this method is considered as an alternative option for the rapid diagnosis of DR-TB cases. However, due to heterogeneity of included studies, the results of HRM assays should be interpreted based on conventional drug susceptibility testing.
\end{abstract}

Keywords: Drug-resistant tuberculosis, High resolution melting, Mycobacterium tuberculosis

\section{Background}

A century after the discovery of Mycobacterium tuberculosis $(M t b)$ as the etiological agent of tuberculosis (TB) by Robert Koch, the disease is still one of the leading causes of death (after AIDS) worldwide [1, 2]. According

\footnotetext{
*Correspondence: mohsen.karbalaei@jmu.ac.ir

${ }^{3}$ Department of Microbiology and Virology, School of Medicine, Jiroft University of Medical Sciences, Jiroft, Iran

Full list of author information is available at the end of the article
}

to the World Health Organization (WHO) report in 2020, approximately 10 million (range, 8.9-11.0 million) people became infected with $M t b$ in 2019; of these, approximately 1.2 million (range, 1.1-1.3 million) deaths occurred among HIV-negative people [3]. Furthermore 208,000 deaths (range, 177,000-242,000) were related to HIV-positive individuals [4]. According to the use of comprehensive treatment programs, statistics show that the number of TB deaths among HIV-positive and 
HIV-negative people fell by $31 \%$ and $69 \%$ between 2000 and 2019, respectively [4]. Drug-resistant tuberculosis (DR-TB) is a global concern for TB control programs, and close to half a million people have been diagnosed with rifampicin-resistant TB (RR-TB); of which 78\% had MDR-TB (resistant to both rifampicin and isoniazid). Three countries, India (27\%), China (14\%), and Russian Federation $(8 \%)$ had the largest share of the global MDR-TB burden, respectively $[4,5]$. Therefore, prompt diagnosis and appropriate treatment of both $\mathrm{TB}$ and DR-TB cases are considered as key factors in reducing mortality from this disease [6, 7]. According to WHO guidelines, diagnosis of both resistance and susceptible isolates requires methods such as molecular techniques, cultivation, sequencing, and bacteriological confirmation; although methods e.g. culture (in LJ, 7H10, 7H11 and MGIT media) and phenotypic drug susceptibility testing (DST) are considered as gold standard methods for diagnosis of this bacterium, however, these methods are time-consuming, laborious, and sometimes ambiguous results are obtained $[4,8]$. Therefore, reducing the detection time leads to reduce the risk of transmission of resistant strains [9]. In recent years, several rapid methods for diagnosing TB or DR-TB isolates such as PCR, real-time PCR, line probe assay (LPA), Xpert MTB/RIF assay, and BACTEC MGIT 960 liquid culture have been introduced [8]. Xpert MTB/RIF assay is applicable in high-prevalence and low-income settings; although this method has recently been approved by WHO for rapid detection of both $M t b$ and RR-TB isolates, it has several disadvantages, for example, it is only used for rifampin and is not affordable in all regions of developing countries [8-11]. BACTEC system is based on the generation of radioactive $\mathrm{CO}_{2}$ from substrate palmitic acid; this system is high specific and helpful in distinguishing $M t b$ from other mycobacteria, as well as is used as a comparative method versus DST. In general, in this system growth can be detected in 5-10 days; however, the detection time of bacteria in this method is faster than the conventional culture method (more than two weeks), but it takes more time to detect than molecular methods [12]. Overall, molecular methods are more rapid compared to other methods, nevertheless, these methods are costly, and also require standardization and a multi-step process; moreover, the use of these methods increases the risk of cross-contamination and misdiagnosis [13]. High resolution melting (HRM) assay is a new method to detect point mutations, single nucleotide polymorphism (SNP), and internal tandem duplications [14, 15]. HRM technique is based on differences in the melting profiles of test and reference DNAs; in this method, using realtime PCR assay, first, immunofluorescent dyes bind to double-stranded DNA, and during the denaturation step of PCR amplicons, differences in melting curves indicate that a mutation occurs in the test DNAs compared to reference DNA [16]. The recent method is relatively inexpensive and requires only unlabeled primers and dsDNA binding dyes; the process of detection is too fast, and due to the reaction in a closed tube, the risk of contamination is low; unlike other molecular methods, this method has no post-PCR process $[17,18]$. To date, various studies have examined the sensitivity and specificity of HRM, and the aim of this meta-analysis was to determine the overall accuracy of HRM in identifying DR-TB cases.

\section{Methods \\ Literature search strategy}

The systematic review was performed based on preferred reporting items for systematic reviews and meta-analysis (PRISMA) guideline [19]. At the first, a comprehensive literature search| |was| |conducted| "using global databases such as "Web of Science, PubMed, Scopus, Cochrane Library, and Google scholar. Relevant studies were retrieved according to keywords such as "Mycobacterium tuberculosis", "Tuberculosis", “TB", "Drug-resistant TB", "High resolution melting", "Specificity", and "Sensitivity". Studies were selected regardless of publication date, and we also evaluated the bibliography of all candidate articles to identify duplicate studies.

\section{Study screening and selection}

To determine the eligibility of studies, title, abstract, and full text of potential studies were evaluated. This process was conducted by two authors separately, and disagreements were resolved through discussion. Our inclusion criteria included: (1) original articles on HRM value for diagnosis of DR-TB; (2) evaluated studies by reference tests (antibiogram, BACTEC MGIT 960 system, sequencing) and HRM; (3) studies containing information such as true positive (TP), false positive (FP), true negative (TN), and false negative (FN); (4) English studies. In the present study, excluded criteria were including: (I) congress abstracts, letters, and review articles; (II) articles with unclear results and insufficient data; (III) studies on extrapulmonary TB; (IV) non-English studies. Finally, 24 articles met our included criteria [20-43].'

\section{Data extraction and quality assessment}

In this step, we used the Newcastle-Ottawa Scale (NOS) to assess the quality of included studies. Information such as first author, publication year, country, subjects, number of $M t b$ (resistant and susceptible) isolates, studied genes, and number of TP/FP/TN/FN for each participant are listed in Table 1. 
Table 1 Characteristic of included studies

\begin{tabular}{|c|c|c|c|c|c|c|c|c|c|c|c|}
\hline Author & Year & Country & Subjects & $\mathrm{R} / \mathrm{S}$ & Gene & $\mathrm{TP}(\mathrm{n})$ & $\mathrm{FP}(\mathrm{n})$ & $\mathrm{FN}(\mathrm{n})$ & $\mathrm{TN}(\mathrm{n})$ & NOS & Refs. \\
\hline Pietzka & 2009 & Austria & Multidrug-resistant TB & $49 / 19$ & $r p o B$ & 44 & 2 & 5 & 17 & 8 & [18] \\
\hline Choi & 2010 & Korea & $\begin{array}{l}\text { Isoniazid resistance } \\
\text { Rifampicin resistance }\end{array}$ & $\begin{array}{l}100 / 117 \\
73 / 124\end{array}$ & $\begin{array}{l}\text { katG, inhA } \\
\text { rpoB }\end{array}$ & $\begin{array}{l}90 \\
72\end{array}$ & $\begin{array}{l}0 \\
0\end{array}$ & $\begin{array}{l}10 \\
1\end{array}$ & $\begin{array}{l}117 \\
124\end{array}$ & 10 & {$[19]$} \\
\hline Ong & 2010 & Singapore & $\begin{array}{l}\text { Isoniazid resistance } \\
\text { Rifampicin resistance }\end{array}$ & $\begin{array}{l}53 / 6 \\
28 / 31\end{array}$ & $\begin{array}{l}\text { katG and mab-inhA } \\
\text { rpoB }\end{array}$ & $\begin{array}{l}52 \\
25\end{array}$ & $\begin{array}{l}1 \\
0\end{array}$ & $\begin{array}{l}1 \\
3\end{array}$ & $\begin{array}{l}5 \\
31\end{array}$ & 8 & {$[20]$} \\
\hline Ramirez & 2010 & United States & Multidrug-resistant TB & $148 / 104$ & $\begin{array}{l}\text { katG, inhA } \\
\text { rpoB }\end{array}$ & 126 & 2 & 22 & 102 & 8 & {$[21]$} \\
\hline Wang & 2011 & China & Streptomycin resistance & $30 / 0$ & $r p s L$ & 21 & 0 & 9 & 0 & 5 & {$[22]$} \\
\hline Chen & 2011 & Australia & $\begin{array}{l}\text { Isoniazid resistance } \\
\text { Rifampicin resistance } \\
\text { Ofloxacin resistance }\end{array}$ & $\begin{array}{l}69 / 46 \\
54 / 61 \\
41 / 74\end{array}$ & $\begin{array}{l}\text { katG and mab-inhA } \\
\operatorname{rpoB} \\
\text { gyrA }\end{array}$ & $\begin{array}{l}67 \\
51 \\
41\end{array}$ & $\begin{array}{l}0 \\
1 \\
1\end{array}$ & $\begin{array}{l}2 \\
3 \\
0\end{array}$ & $\begin{array}{l}48 \\
60 \\
73\end{array}$ & 9 & {$[23]$} \\
\hline Lee & 2012 & Singapore & $\begin{array}{l}\text { Fluoroquinolone and } \\
\text { Streptomycin resistance }\end{array}$ & $\begin{array}{l}25 / 28 \\
48 / 14\end{array}$ & $\begin{array}{l}\text { gyrA } \\
\text { rpsL }\end{array}$ & $\begin{array}{l}19 \\
42\end{array}$ & $\begin{array}{l}0 \\
0\end{array}$ & $\begin{array}{l}6 \\
6\end{array}$ & $\begin{array}{l}28 \\
14\end{array}$ & 7 & {$[24]$} \\
\hline Yadav & 2012 & India & $\begin{array}{l}\text { Isoniazid resistance } \\
\text { Rifampicin resistance } \\
\text { Streptomycin resistance }\end{array}$ & $\begin{array}{l}35 / 20 \\
29 / 20 \\
34 / 20\end{array}$ & $\begin{array}{l}\text { katG } \\
\text { rpoB } \\
\text { rpsL }\end{array}$ & $\begin{array}{l}30 \\
27 \\
21\end{array}$ & $\begin{array}{l}2 \\
0 \\
0\end{array}$ & $\begin{array}{l}5 \\
2 \\
13\end{array}$ & $\begin{array}{l}18 \\
20 \\
20\end{array}$ & 9 & {$[25]$} \\
\hline Nagai & 2013 & Japan & $\begin{array}{l}\text { Isoniazid resistance } \\
\text { Rifampicin resistance } \\
\text { Ethambutol resistance } \\
\text { Streptomycin resistance }\end{array}$ & $\begin{array}{l}12 / 15 \\
10 / 17 \\
8 / 19 \\
11 / 16\end{array}$ & $\begin{array}{l}\text { katG, mab-inhA } \\
r p o B \\
\text { embB } \\
\text { rpsL, rrs }\end{array}$ & $\begin{array}{l}11 \\
10 \\
8 \\
11\end{array}$ & $\begin{array}{l}0 \\
2 \\
0 \\
1\end{array}$ & $\begin{array}{l}1 \\
0 \\
0 \\
0\end{array}$ & $\begin{array}{l}15 \\
15 \\
19 \\
15\end{array}$ & 10 & {$[26]$} \\
\hline Nour & 2013 & Egypt & $\begin{array}{l}\text { Isoniazid resistance } \\
\text { Rifampicin resistance }\end{array}$ & $\begin{array}{l}20 / 10 \\
13 / 17\end{array}$ & katG, rpoB & $\begin{array}{l}17 \\
12\end{array}$ & $\begin{array}{l}0 \\
0\end{array}$ & $\begin{array}{l}3 \\
1\end{array}$ & $\begin{array}{l}10 \\
17\end{array}$ & 6 & {$[27]$} \\
\hline Haeili & 2014 & Iran & $\begin{array}{l}\text { Isoniazid resistance } \\
\text { Rifampicin resistance }\end{array}$ & $\begin{array}{l}21 / 54 \\
20 / 54\end{array}$ & $\begin{array}{l}\text { katG } \\
\text { rpoB }\end{array}$ & $\begin{array}{l}18 \\
19\end{array}$ & $\begin{array}{l}0 \\
0\end{array}$ & $\begin{array}{l}3 \\
1\end{array}$ & $\begin{array}{l}54 \\
54\end{array}$ & 8 & {$[28]$} \\
\hline Pholwat & 2014 & United States & Pyrazinamide resistance & $55 / 41$ & pncA & 34 & 7 & 21 & 34 & 8 & {$[29]$} \\
\hline Malhotra & 2015 & India & Rifampicin resistance & $103 / 116$ & $r p o B$ & 93 & 3 & 10 & 113 & 9 & {$[30]$} \\
\hline Pholwat & 2015 & United states & Drug-resistant TB & $\begin{array}{l}186 / 41 \\
161 / 58 \\
80 / 123 \\
107 / 304 \\
40 / 180 \\
56 / 57\end{array}$ & $\begin{array}{l}\text { inhA or katG } \\
r p o B \\
\text { embB } \\
r p s L, r r s, \text { eis } \\
\text { gyrA-gyrB } \\
\text { pncA }\end{array}$ & $\begin{array}{l}174 \\
153 \\
62 \\
89 \\
31 \\
49\end{array}$ & $\begin{array}{l}0 \\
11 \\
35 \\
18 \\
3 \\
2\end{array}$ & $\begin{array}{l}12 \\
8 \\
18 \\
18 \\
9 \\
7\end{array}$ & $\begin{array}{l}41 \\
47 \\
88 \\
286 \\
177 \\
55\end{array}$ & 10 & {$[31]$} \\
\hline Osman & 2016 & Africa & Pyrazinamide resistance & $29 / 66$ & pncA & 14 & 17 & 15 & 49 & 7 & {$[32]$} \\
\hline Galarza & 2016 & Peru & $\begin{array}{l}\text { Multidrug-resistant TB } \\
\text { Isoniazid resistance } \\
\text { Rifampicin resistance }\end{array}$ & $\begin{array}{l}78 / 89 \\
78 / 89 \\
78 / 89\end{array}$ & $\begin{array}{l}\text { katG, inhA } \\
\text { rpoB }\end{array}$ & $\begin{array}{l}77 \\
77 \\
77\end{array}$ & $\begin{array}{l}2 \\
2 \\
0\end{array}$ & $\begin{array}{l}1 \\
1 \\
1\end{array}$ & $\begin{array}{l}87 \\
87 \\
89\end{array}$ & 8 & {$[33]$} \\
\hline Anthwal & 2017 & India & $\begin{array}{l}\text { Isoniazid resistance } \\
\text { Rifampicin resistance }\end{array}$ & $\begin{array}{l}21 / 78 \\
11 / 88\end{array}$ & $\begin{array}{l}\text { katG, inhA } \\
\text { rpoB }\end{array}$ & $\begin{array}{l}18 \\
10\end{array}$ & $\begin{array}{l}0 \\
0\end{array}$ & $\begin{array}{l}3 \\
1\end{array}$ & $\begin{array}{l}88 \\
88\end{array}$ & 9 & {$[34]$} \\
\hline Rezaei & 2017 & Iran & $\begin{array}{l}\text { Ethambutol resistance } \\
\text { Streptomycin resistance }\end{array}$ & $\begin{array}{l}21 / 55 \\
25 / 51\end{array}$ & $\begin{array}{l}\text { embB } \\
\text { rrs, rpsL }\end{array}$ & $\begin{array}{l}19 \\
22\end{array}$ & $\begin{array}{l}2 \\
0\end{array}$ & $\begin{array}{l}2 \\
3\end{array}$ & $\begin{array}{l}53 \\
51\end{array}$ & 6 & {$[35]$} \\
\hline Sirous & 2018 & Iran & $\begin{array}{l}\text { Isoniazid resistance } \\
\text { Rifampicin resistance } \\
\text { Ofloxacin resistance }\end{array}$ & $\begin{array}{l}16 / 20 \\
18 / 20 \\
5 / 20\end{array}$ & $\begin{array}{l}\text { katG and mab-inhA } \\
\text { rpoB } \\
\text { gyrA }\end{array}$ & $\begin{array}{l}14 \\
15 \\
4\end{array}$ & $\begin{array}{l}0 \\
0 \\
0\end{array}$ & $\begin{array}{l}2 \\
3 \\
1\end{array}$ & $\begin{array}{l}20 \\
20 \\
20\end{array}$ & 10 & {$[36]$} \\
\hline Negi & 2018 & India & Multidrug-resistant TB & $94 / 49$ & katG, rpoB & 85 & 0 & 9 & 49 & 8 & {$[37]$} \\
\hline Filipenko & 2019 & Russia & Pyrazinamide resistance & $38 / 20$ & pncA & 31 & 3 & 7 & 17 & 7 & {$[38]$} \\
\hline Arefzadeh & 2020 & Iran & Rifampicin resistance & $5 / 75$ & $r p o B$ & 5 & 8 & 0 & 67 & 8 & {$[39]$} \\
\hline Anukool & 2020 & Thailand & $\begin{array}{l}\text { Isoniazid resistance } \\
\text { Rifampicin resistance }\end{array}$ & $\begin{array}{l}34 / 69 \\
37 / 70\end{array}$ & $\begin{array}{l}\text { katG, inhA } \\
\text { rpoB }\end{array}$ & $\begin{array}{l}33 \\
31\end{array}$ & $\begin{array}{l}4 \\
1\end{array}$ & $\begin{array}{l}1 \\
6\end{array}$ & $\begin{array}{l}65 \\
69\end{array}$ & 9 & {$[40]$} \\
\hline Wang & 2020 & China & Ethambutol resistance & $59 / 163$ & $e m b B$ & 49 & 9 & 10 & 154 & 7 & {$[41]$} \\
\hline
\end{tabular}

\section{Statistical analysis}

The accuracy and reliability of HRM method were measured using indexes such as sensitivity, specificity, and diagnostic odds ratio (DOR) with $95 \%$ confidence interval (CI). Subsequently, we employed summary receiver operating characteristic (SROC) curve to measure the area under the curve (AUC) [44]. In addition, Chisquared and I-squared tests $\left(\mathrm{p}<0.01\right.$ or $\left.I^{2}>50 \%\right)$ were used to measure heterogeneity between studies. Based on significant heterogeneity between studies, we conducted 
a pooled analysis (fixed-effects model or random-effects model). Furthermore bl subgroup analysis was performed individually $\mid$ to assess the accuracy of HRM assay for two types of DR-TB including, mono-resistant TB (rifampin, isoniazid, ethambutol, streptomycin, pyrazinamide, or fluoroquinolone) and MDR-TBi. All statistical|ttests |were two-sided with a significant cut-off $(\mathrm{p}<0.05)$, and were fulfilled by Meta-DiSc software.

\section{Results}

\section{Characterization of included studies}

After an initial evaluation of the retrieved articles, finally 24 studies were accordance with our criteria (Fig. 1). Included studies had been published in Austria, Korea, Singapore, United States, China, India, Iran, Japan, Egypt, Africa, Peru, Russia, and Thailand during 2009-2020. In this study, data from $4732 \mathrm{Mtb}$ isolates (both drugresistant and drug-susceptible strains) were studied. In all eligible studies, authors had assessed the accuracy and integrity of HRM assay for both first-line (isoniazid, rifampin, streptomycin, ethambutol, pyrazinamide, and MDR-TB) and second-line (particularly ofloxacine) treatments, using standard methods such as sequencing, MGIT 960, and proportional method (Table 1). In these studies, different primers were designed related to antibiotic resistance including katG, mab-inhA, rpoB, rrs, rpsL, eis, embB, pncA, gyrA', and gyrB. Quality assessments showed that most included studies had a low risk of bias, which confirmed the proportion of selected studies.

\section{Meta-analysis results}

The results obtained from forest plots showed that the sensitivity and specificity of HRM were acceptable for distinguishing DR-TB strains from susceptible strains. According to statistical analysis, the sensitivity and specificity of DR-TB cases were $89 \%$ (95\% CI: 88-90) and 95\% (95\% CI: 94-96), respectively. However, the $I^{2}$ values for sensitivity and specificity were higher than $50 \%$, which indicated a significant heterogeneity. The diagnostic accuracy of HRM was measured by SROC curve, so that the AUC and Q* values were 0.9754 and 0.9289 , respectively.

\section{Subgroup analysis}

Due to a significant heterogeneity in the estimated results, we performed subgroup analysis to discover the source of heterogeneity. Each of 47 studies independently had measured $M t b$ resistance to isoniazid, rifampin, ethambutol, streptomycin, pyrazinamide, fluoroquinolones MDR-TB, and first line. Parameters such as sensitivity, specificity, diagnostic ORs, and SROC for these antibiotics are listed in Table 2.

According to the results of subgrouping analysis, HRM is a reliable method for diagnosis of DR-TB cases, in particular the sensitivity and specificity for isoniazid, rifampin, and MDR-TB was higher than 90\%. Furthermore, this method accurately discriminates resistance and susceptibility to other antibiotics such as ethambutol, streptomycin, pyrazinamide, and fluoroquinolones.

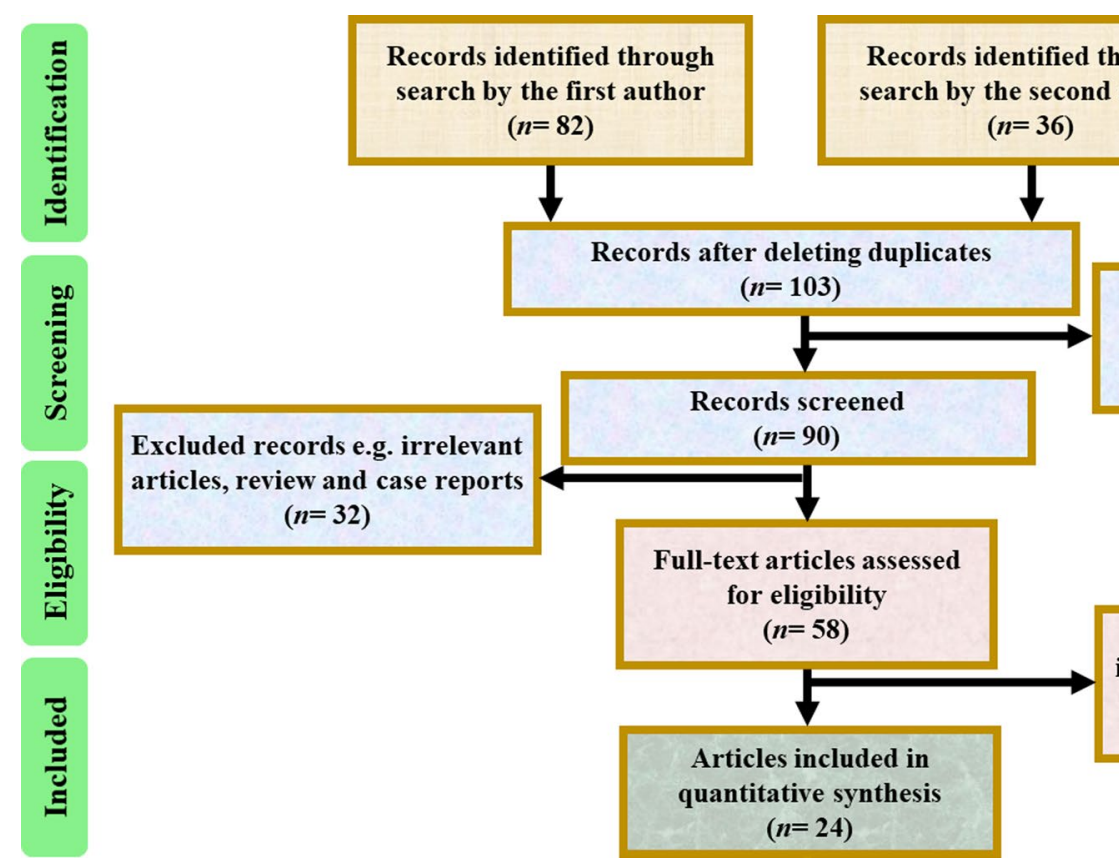

Excluded records based on title and language $(n=13)$

Excluded records e.g. insufficient data, unavailable, non human sample $(n=34)$

Fig. 1 Flowchart of the selection of excluded and includedstudies 
Table 2 Pooled means of sensitivity and specificity, DOR, and SROC for each antibiotics

\begin{tabular}{|c|c|c|c|c|c|}
\hline \multirow[t]{2}{*}{ Drugs } & \multirow[t]{2}{*}{ Sensitivity $(95 \% \mathrm{Cl})$} & \multirow[t]{2}{*}{ Specificity $(95 \% \mathrm{Cl})$} & \multirow[t]{2}{*}{ DOR $(95 \% \mathrm{Cl})$} & \multicolumn{2}{|l|}{ SROC } \\
\hline & & & & $\overline{A U C}$ & $\mathrm{Q}^{*}$ \\
\hline Isoniazid & $93 \%(91-95)$ & $98 \%(97-99)$ & 459.85 (198.64-1064.55) & 0.987 & 0.953 \\
\hline Rifampin & $94 \%(92-95)$ & $97 \%(95-98)$ & $414.98(182.7-942.6)$ & 0.963 & 0.935 \\
\hline Ethambutol & $82 \%(75-88)$ & $87 \%(83-90)$ & $69.50(10.57-457.09)$ & 0.728 & 0.794 \\
\hline Streptomycin & $82 \%(77-87)$ & $95 \%(93-97)$ & $92.82(49.36-174.55)$ & 0.957 & 0.900 \\
\hline Pyrazinamide & $72 \%(65-78)$ & $84 \%(78-89)$ & $16.11(3.11-83.5)$ & 0.845 & 0.777 \\
\hline MDR-TB & $90 \%(86-93)$ & $98 \%(95-99)$ & $404.41(87.02-1879.41)$ & 0.989 & 0.956 \\
\hline fluoroquinolones & $86 \%(78-92)$ & $99 \%(97-100)$ & 274.63 (83.71-901.02) & 0.997 & 0.980 \\
\hline First-line & $89 \%(88-90)$ & $95 \%(94-96)$ & $232.05(121.50-443.21)$ & 0.973 & 0.925 \\
\hline
\end{tabular}

The SROC curves represented the maximum polymerization spots of sensitivity and specificity associated with each of HRM assay (Fig. 2).

\section{Discussion}

In recent years, the emergence of DR-TB strains is accounted a serious threat to TB control worldwide [45].
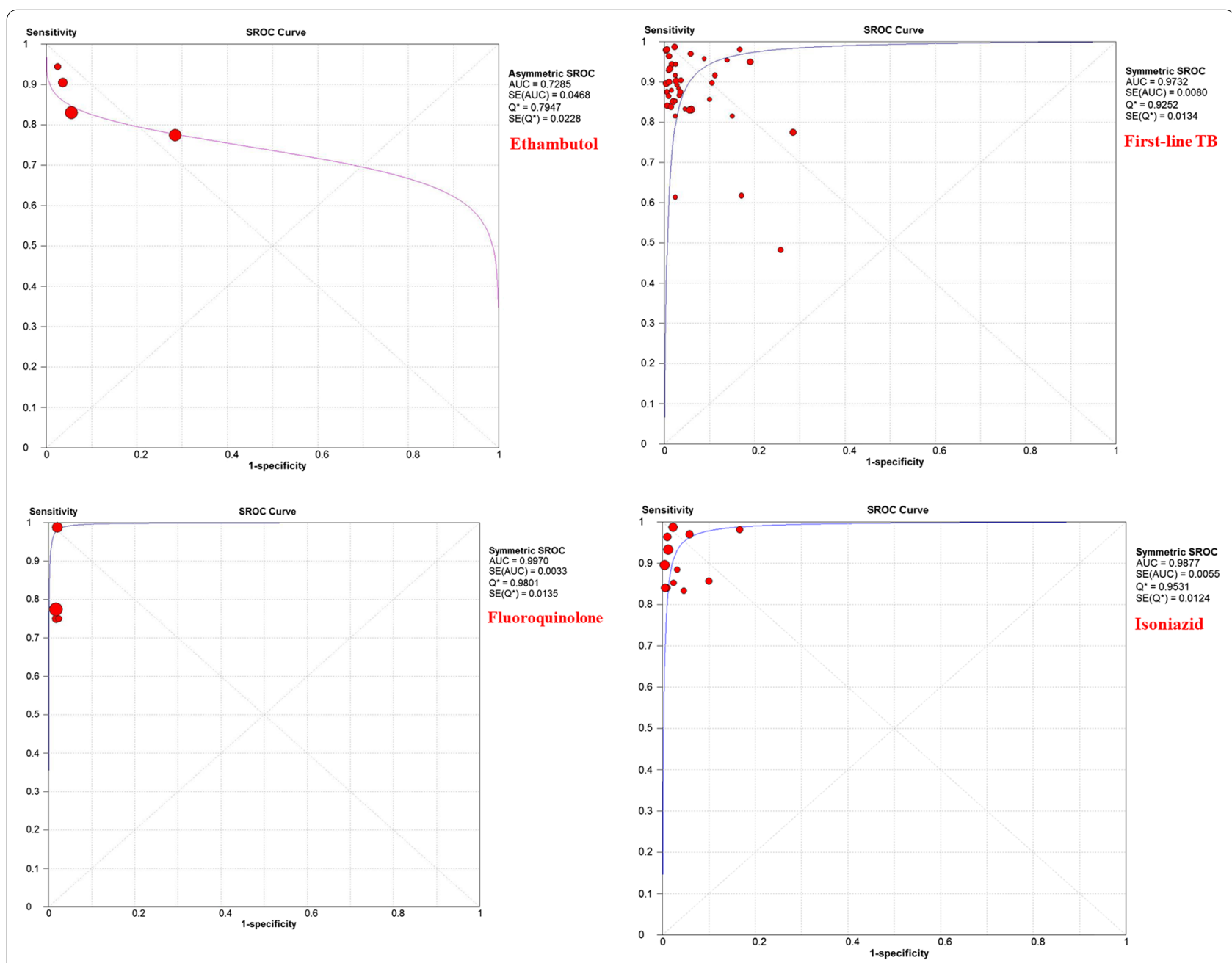

Fig. 2 Summary Receiver Operating Characteristic curves ofeach antibiotic for discriminating drug-resistant TB cases (2.1: ethambutol,2.2: first-line TB, 2.3: fluoroquinolone, 2.4: isoniazid, 2.5: MDR-TB, 2.6:pyrazinamide, 2.7: rifampin, and 2.8: streptomycin) 

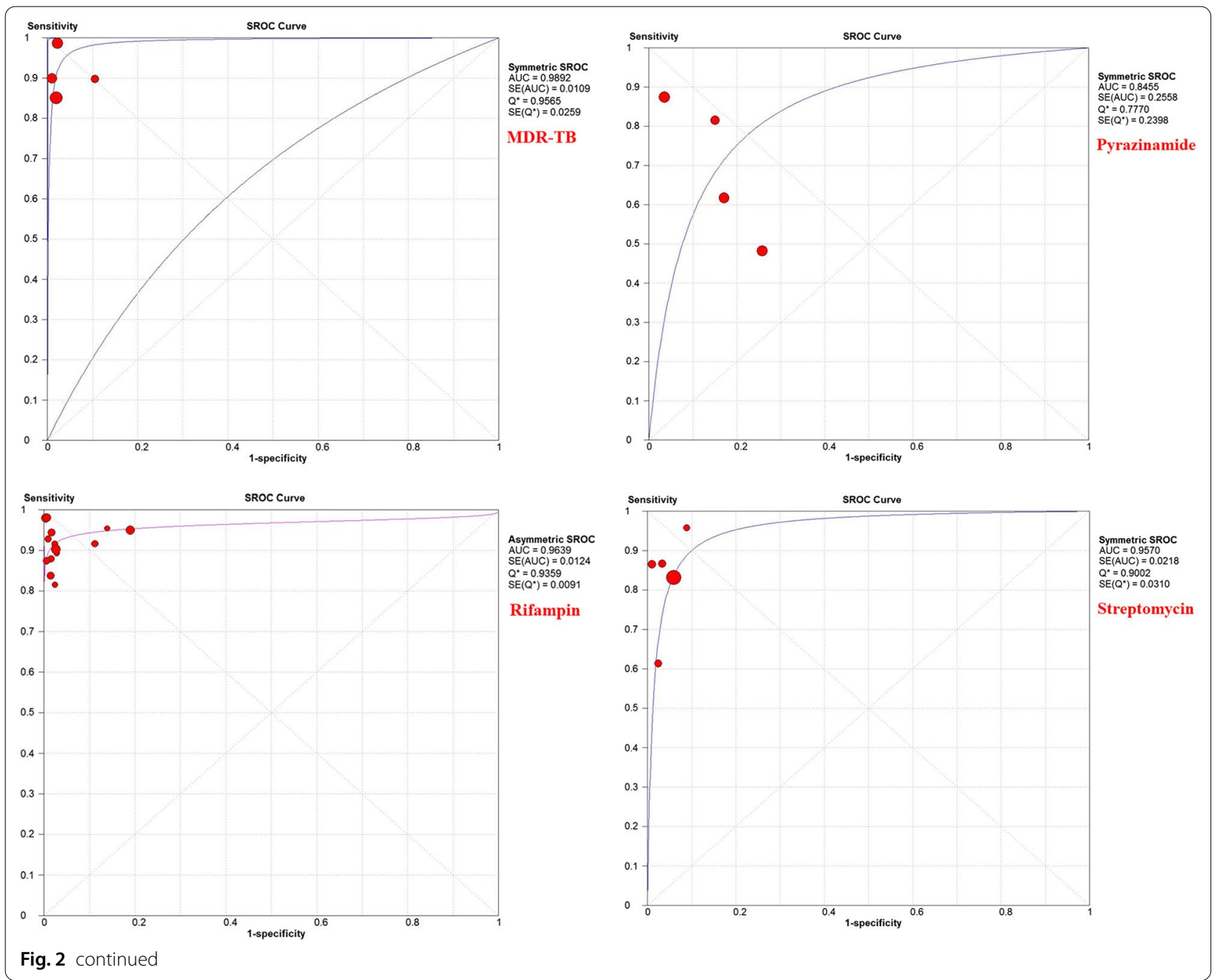

Diagnosis and screening of patients infected with MDR and extensively drug-resistant (XDR) strains is an important strategy to monitor and prevent the geographical spread of DR-TB strains [46]. Although conventional drug susceptibility testing such as proportional method, absolute concentration method, and resistance ratio method are known as reference methods, these are timeconcuming and laborious [47]. To date, conventional drug susceptibility testing by liquid culture system has been introduced as colorimetric redox-indicator method, which in turn reduces the detection time to less than a week, but this system requires expensive tools and cannot be used in all developing countries [48, 49]. The Xpert $\mathrm{MTB} / \mathrm{RIF}$ assay is a relatively new method recommended by WHO, but it should be noted that this method is only able to detect rifampin-resistant cases [50]. Among the molecular methods that can be used to determine TB antibiotic resistance, HRM is a fast, inexpensive, and simple method, which can detect different mutations using a small number of probes or even without a special probe [51]. In their meta-analysis study (using 7 articles), Yin et al. showed that the sensitivity and specificity of HRM in the diagnosing of rifampin-resistant TB cases were $94 \%$ and $99 \%$, respectively [18]. A summary of common methods for detecting drug-resistant $\mathrm{TB}$ are listed in Table 3.

To date, many studies have examined the accuracy of HRM for the diagnosis of DR-TB, however, no study has systematically evaluated the effectiveness of this method. In the present meta-analysis, we estimated the sensitivity and specificity of HRM in detecting DR-TB cases at $89 \%$ and $95 \%$, respectively. According to our results, accuracy of HRM was slightly higher than other molecular methods, especially PCR-SSCP, while it was lower compared to the conventional drug susceptibility testing method. HRM method is credible method for detecting of mutations in specific genes; approximately $95 \%$ of rifampinrelated mutations occur in the rifampicin resistance 


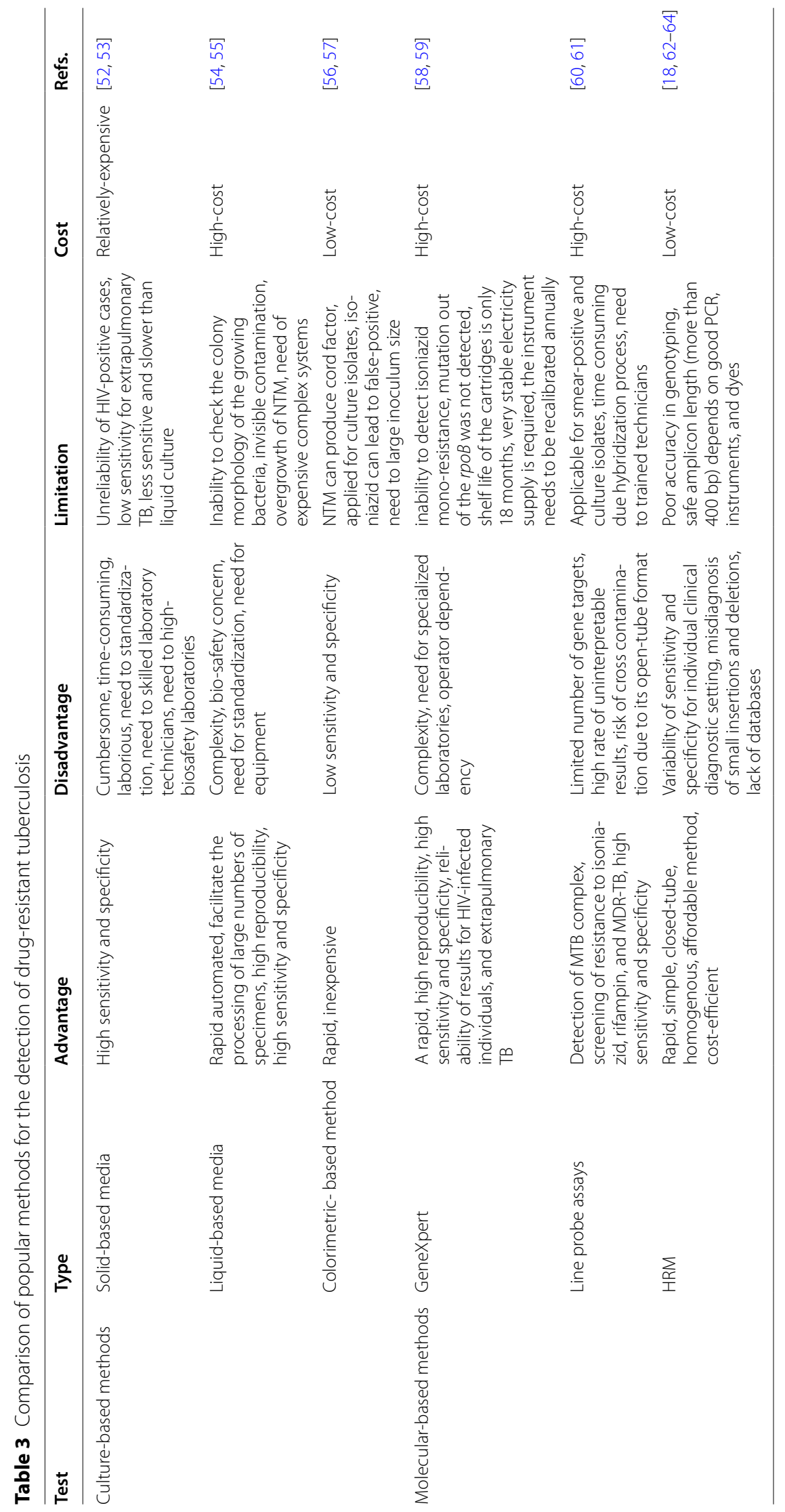


determining region (RRDR), while, $5 \%$ of those are outside this locus and cannot be detected by conventional molecular methods [65]. Nevertheless, some mutations such as nucleotide transversions (A:T and G:C) are difficult to distinguish, since they have very little influence on the overall thermal denaturation profile [66]. Sharma et al. showed that HRM could be a rapid and reliable method for the diagnosis of MDR-TB in cases of extrapulmonary TB [67]. In another study, Mu et al. examined this method for detecting DR-TB in formalinfixed or paraffin-embedded tissues; they found that the sensitivity of HRM for antibiotics such as rifampin, isoniazid, levofloxacin, and moxifloxacin was was $95.00 \%$, $96.00 \%, 100 \%$, and $100 \%$, respectively, while its specificity was $95.15 \%, 95.92 \%, 94.69 \%$, and $89.92 \%$, respectively [68]. The stability of our findings are confirmed by similar studies and our results also showed that HRM is a trustworthy method for detecting resistance to some antibiotics, especially isoniazid and rifampin. In the present study, the heterogeneity was significant in some cases so that it was not eliminated by subgroup analysis; this issue requires a comprehensive program. This phenomenon may be due to differences in some factors such as study design, low sample size, references methods, examining tools, and dyes used. Despite its reliability, HRM has disadvatages including: (1) this method is performed only on cultured isolates; (2) HRM results are strongly depend on the quality of the extracted DNA; (3) researchers use a variety of protocols to set up HRM (self-design program). Our study had several limitations: (1) low sample size; (2) potential heterogeneity due to differences in study design and also unreliability of results; (3) inaccessibility to raw data for further analysis; (4) failure to assess the publication bias.

\section{Conclusion}

Despite the limitations of the present study, according to previous studies, we have shown that HRM is an accurate method for diagnosing and monitoring DR-TB cases. This method, together with the results of drug susceptibility testing, seems to be a suitable strategy for rapid and inexpensive diagnosis of DR-TB cases.

\begin{abstract}
Abbreviations
TB: Tuberculosis; DR-TB: Drug-resistant tuberculosis; HRM: High resolution melting; Mtb: Mycobacterium tuberculosis; SROC: Summary receiver operating characteristic; AUC: Curve and the area under the curve; TP: True positive; FP: False positive; TN: True negative; FN: False negative; NOS: Newcastle-Ottawa Scale; PRISMA: Preferred reporting items for systematic reviews and metaanalysis; SNP: Single nucleotide polymorphism.
\end{abstract}

\section{Acknowledgements}

We appreciate from both Mashhad University of Medical Sciences and Jiroft University of Medical Sciences.

\section{Authors' contributions}

1. MK1 have contributed to design of the work and analysis of data. 2. MK2 have drafted the work and substantively revised it. Both authors read and approved the final manuscript.

\section{Funding}

We have not received any funding for this research.

\section{Availability of data and materials}

All data generated or analyzed during this study are included in this published article.

\section{Declarations}

Ethics approval and consent to participate

Not applicable (this paper was provided based on researching in global databases).

\section{Consent for publish \\ Not applicable.}

\section{Competing interests}

The authors declare no competing interests.

\section{Author details}

${ }^{1}$ Department of Microbiology and Virology, Faculty of Medicine, Mashhad University of Medical Sciences, Mashhad, Iran. ${ }^{2}$ Student Research Committee, Mashhad University of Medical Sciences, Mashhad, Iran. ${ }^{3}$ Department of Microbiology and Virology, School of Medicine, Jiroft University of Medical Sciences, Jiroft, Iran.

Received: 16 May 2021 Accepted: 11 September 2021

Published online: 22 September 2021

\section{References}

1. Drain PK, Bajema KL, Dowdy D, Dheda K, Naidoo K, Schumacher SG, Ma S, Meermeier E, Lewinsohn DM, Sherman DR. Incipient and subclinical tuberculosis: a clinical review of early stages and progression of infection. Clin Microbiol Rev. 2018;31:4.

2. Keikha M, Esfahani BN. The relationship between tuberculosis and lung cancer. Adv Biomed Res. 2018;7:1.

3. Keikha M, Karbalaei M. Overview on coinfection of HTLV-1 and tuberculosis: Mini-review. J Clin Tuberc Other Mycobact Dis. 2021;2021:100224.

4. Organization WH: Global tuberculosis report 2020: executive summary. 2020.

5. Keikha M. There is significant relationship between Beijing genotype family strains and resistance to the first-line anti-tuberculosis drugs in the Iranian population. J Clin Tuberc Other Mycobact Dis. 2020;19:1.

6. Weyer K, Dennis Falzon D, Jaramillo E, Zignol M, Mirzayev F, Raviglione M. Drug-resistant tuberculosis: what is the situation, what are the needs to roll it back. AMR control. 2017;20:60-7.

7. Keikha M, Karbalaei M. Antithetical effects of MicroRNA molecules in tuberculosis pathogenesis. Adv Biomed Res. 2019;8:1.

8. Migliori GB, Tiberi S, Zumla A, Petersen E, Chakaya JM, Wejse C, Torrico MM, Duarte R, Alffenaar JW, Schaaf HS. MDR/XDR-TB management of patients and contacts: challenges facing the new decade The 2020 clinical update by the Global Tuberculosis Network. Int J Infect Dis. 2020;92:S15-25.

9. Organization WH. The global MDR-TB \& XDR-TB response plan 20072008. Geneva: World Health Organization; 2007.

10. Jacobson KR, Theron D, Kendall EA, Franke MF, Barnard M, Van Helden PD, Victor TC, Streicher EM, Murray MB, Warren RM. Implementation of GenoType MTBDR plus reduces time to multidrug-resistant tuberculosis therapy initiation in South Africa. Clin Infect Dis. 2013;56(4):503-8.

11. Sohn H, Aero AD, Menzies D, Behr M, Schwartzman K, Alvarez GG, Dan A, McIntosh F, Pai M, Denkinger CM. Xpert MTB/RIF testing in a low 
tuberculosis incidence, high-resource setting: limitations in accuracy and clinical impact. Clin Infect Dis. 2014;58(7):970-6.

12. Bemer P, Palicova F, Rüsch-Gerdes S, Drugeon HB, Pfyffer GE. Multicenter evaluation of fully automated BACTEC Mycobacteria Growth Indicator Tube 960 system for susceptibility testing of Mycobacterium tuberculosis. J Clin Microbiol. 2002;40(1):150-4.

13. Fluit AC, Visser MR, Schmitz F-J. Molecular detection of antimicrobial resistance. Clin Microbiol Rev. 2001;14(4):836-71.

14. Krypuy M, Newnham GM, Thomas DM, Conron M, Dobrovic A. High resolution melting analysis for the rapid and sensitive detection of mutations in clinical samples: KRAS codon 12 and 13 mutations in non-small cell lung cancer. BMC Cancer. 2006;6(1):1-12.

15. Liew M, Nelson L, Margraf R, Mitchell S, Erali M, Mao R, Lyon E, Wittwer C. Genotyping of human platelet antigens 1 to 6 and 15 by high-resolution amplicon melting and conventional hybridization probes. J Mol Diagn. 2006;8(1):97-104.

16. Athamanolap P, Parekh V, Fraley SI, Agarwal V, Shin DJ, Jacobs MA, Wang $\mathrm{T}-\mathrm{H}$, Yang $\mathrm{S}$. Trainable high resolution melt curve machine learning classifier for large-scale reliable genotyping of sequence variants. PLOS ONE. 2014;9(10):e109094.

17. Montgomery JL, Sanford LN, Wittwer CT. High-resolution DNA melting analysis in clinical research and diagnostics. Expert Rev Mol Diagn. 2010;10(2):219-40.

18. Yin X, Zheng L, Liu Q, Lin L, Hu X, Hu Y, Wang Q. High-resolution melting curve analysis for rapid detection of rifampin resistance in Mycobacterium tuberculosis: a meta-analysis. J Clin Microbiol. 2013;51(10):3294-9.

19. Moher D, Shamseer L, Clarke M, Ghersi D, Liberati A, Petticrew M, Shekelle $P$, Stewart LA. Preferred reporting items for systematic review and metaanalysis protocols (PRISMA-P) 2015 statement. Syst Rev. 2015;4(1):1-9.

20. Pietzka AT, Indra A, Stöger A, Zeinzinger J, Konrad M, Hasenberger P, Allerberger F, Ruppitsch W. Rapid identification of multidrug-resistant Mycobacterium tuberculosis isolates by rpoB gene scanning using high-resolution melting curve PCR analysis. J Antimicrob Chemother. 2009;63(6):1121-7.

21. Choi GE, Lee SM, Yi J, Hwang SH, Kim HH, Lee EY, Cho EH, Kim JH, Kim H-J, Chang $\mathrm{CL}$. High-resolution melting curve analysis for rapid detection of rifampin and isoniazid resistance in Mycobacterium tuberculosis clinical isolates. J Clin Microbiol. 2010;48(11):3893-8.

22. Ong DC, Yam W-C, Siu GK, Lee AS. Rapid detection of rifampicin-and isoniazid-resistant Mycobacterium tuberculosis by high-resolution melting analysis. J Clin Microbiol. 2010;48(4):1047-54.

23. Ramirez MV, Cowart KC, Campbell PJ, Morlock GP, Sikes D, Winchell JM, Posey JE. Rapid detection of multidrug-resistant Mycobacterium tuberculosis by use of real-time PCR and high-resolution melt analysis. J Clin Microbiol. 2010;48(11):4003-9.

24. Wang $F$, Shen $H$, Guan $M$, Wang $Y$, Feng $Y$, Weng $X$, Wang $H$, Zhang $W$. High-resolution melting facilitates mutation screening of rps $L$ gene associated with streptomycin resistance in Mycobacterium tuberculosis. Microbiol Res. 2011;166(2):121-8.

25. Chen X, Kong F, Wang Q, Li C, Zhang J, Gilbert GL. Rapid detection of isoniazid, rifampin, and ofloxacin resistance in Mycobacterium tuberculosis clinical isolates using high-resolution melting analysis. J Clin Microbiol. 2011:49(10):3450-7.

26. Lee AS, Ong DC, Wong JC, Siu GK, Yam W-C. High-resolution melting analysis for the rapid detection of fluoroquinolone and streptomycin resistance in Mycobacterium tuberculosis. PLoS ONE. 2012;7(2):e31934.

27. Yadav R, Sethi S, Mewara A, Dhatwalia S, Gupta D, Sharma M. Rapid detection of rifampicin, isoniazid and streptomycin resistance in $\mathrm{M}$ ycobacterium tuberculosis clinical isolates by high-resolution melting curve analysis. J Appl Microbiol. 2012;113(4):856-62.

28. Nagai Y, Iwade Y, Hayakawa E, Nakano M, Sakai T, Mitarai S, Katayama M, Nosaka T, Yamaguchi T. High resolution melting curve assay for rapid detection of drug-resistant Mycobacterium tuberculosis. J Infect Chemother. 2013;19(6):1116-25

29. Nour MS, El-Shokry MH, Shehata IH, Aziz A. Evaluation of rezasurin microtiter assay and high resolution melting curve analysis for detection of rifampicin and isoniazid resistance of Mycobacterium tuberculosis clinical isolates. Clin Lab. 2013;59(7):763-71.

30. Haeili M, Fooladi A, Bostanabad S, Sarokhalil D, Siavoshi F, Feizabadi M. Rapid screening of rpoB and katG mutations in Mycobacterium tuberculosis isolates by high-resolution melting curve analysis. Indian J Med Microbiol. 2014;32(4):398.

31. Pholwat S, Stroup S, Gratz J, Trangan V, Foongladda S, Kumburu H, Juma SP, Kibiki G, Houpt E. Pyrazinamide susceptibility testing of Mycobacterium tuberculosis by high resolution melt analysis. Tuberculosis. 2014;94(1):20-5.

32. Malhotra B, Goyal S, Bhargava S, Reddy P, Chauhan A, Tiwari J. Rapid detection of rifampicin resistance in Mycobacterium tuberculosis by high-resolution melting curve analysis. Int J Tuberc Lung Dis. 2015;19(12):1536-41.

33. Pholwat S, Liu J, Stroup S, Gratz J, Banu S, Rahman SM, Ferdous SS, Foongladda S, Boonlert D, Ogarkov O. Integrated microfluidic card with TaqMan probes and high-resolution melt analysis to detect tuberculosis drug resistance mutations across 10 genes. MBio. 2015;6:2.

34. Osman F, Ismail F, Osman A, Omar S, Said H, Ismail N. High resolution melting curve analysis for rapid detection of pyrazinamide resistance in Mycobacterium tuberculosis clinical isolates. J Tuberc Res. 2016;4(04):155.

35. Galarza M, Fasabi M, Levano KS, Castillo E, Barreda N, Rodriguez M, Guio $\mathrm{H}$. High-resolution melting analysis for molecular detection of multidrug resistance tuberculosis in Peruvian isolates. BMC Infect Dis. 2016;16(1):1-6.

36. Anthwal D, Gupta RK, Bhalla M, Bhatnagar S, Tyagi JS, Haldar S. Direct detection of rifampin and isoniazid resistance in sputum samples from tuberculosis patients by high-resolution melt curve analysis. J Clin Microbiol. 2017:55(6):1755-66.

37. Rezaei F, Haeili M, Fooladi Al, Feizabadi MM. High resolution melting curve analysis for rapid detection of streptomycin and ethambutol resistance in Mycobacterium tuberculosis. Maedica. 2017;12(4):246.

38. Sirous M, Khosravi AD, Tabandeh MR, Salmanzadeh S, Ahmadkhosravi N, Amini S. Molecular detection of rifampin, isoniazid, and ofloxacin resistance in Iranian isolates of Mycobacterium tuberculosis by high-resolution melting analysis. Infect Drug Resist. 1819;2018:11.

39. Negi SS, Singh P, Bhargava A, Chandrakar S, Gaikwad U, Das P, Behra A. Effective pragmatic approach of diagnosis of multidrug-resistant tuberculosis by high-resolution melt curve assay. Int J Mycobacteriol. 2018;7(3):228.

40. Filipenko M, Dymova M, Cherednichenko A, Khrapov E, Mishukova O, Schwartz YS. Detection of Mutations in Mycobacterium tuberculosis pncA gene by modified high-resolution melting curve analysis of PCR products. Bull Exp Biol Med. 2019;168(2):264-9.

41. Arefzadeh S, Azimi T, Nasiri MJ, Nikpor Z, Dabiri H, Doustdar F, Goudarzi H, Allahyartorkaman M. High-resolution melt curve analysis for rapid detection of rifampicin resistance in Mycobacterium tuberculosis: a single-centre study in Iran. New Microb New Infect. 2020;35:100665.

42. Anukool U, Phunpae P, Tharinjaroen CS, Butr-Indr B, Saikaew S, Netirat N, Intorasoot S, Suthachai V, Tragoolpua K, Chaiprasert A. Genotypic distribution and a potential diagnostic assay of multidrug-resistant tuberculosis in Northern Thailand. Infect Drug Resist. 2020;13:3375.

43. Wang J, Zhao W, Liu R, Huo F, Dong L, Xue Y, Wang Y, Xue Z, Ma L, Pang Y. Rapid detection of ethambutol-resistant Mycobacterium tuberculosis from sputum by high-resolution melting analysis in Beijing China. Infect Drug Resist. 2020;13:3707.

44. Keikha M, Karbalaei M: P2X7 polymorphism (rs3751143) and its reliability as a diagnostic biomarker for tuberculosis: a systematic review and metaanalysis. Indian J Tuberc 2021.

45. Keikha M, Eslami M, Yousefi B, Karbalaei M. Overview of multistage subunit tuberculosis vaccines: advantages and challenges. Reviews in Medical Microbiology. 2020;31(3):144-9.

46. Dey T, Brigden G, Cox H, Shubber Z, Cooke G, Ford N. Outcomes of clofazimine for the treatment of drug-resistant tuberculosis: a systematic review and meta-analysis. J Antimicrob Chemother. 2013;68(2):284-93.

47. Van Deun A, Martin A, Palomino JC: Diagnosis of drug-resistant tuberculosis: reliability and rapidity of detection [State of the art series. Drugresistant tuberculosis. Edited by CY. Chiang. Number 3 in the series]. Int $\mathrm{J}$ Tuberc Lung Dis 2010, 14(2):131-140.

48. Pai M, Kalantri S, Pascopella L, Riley LW, Reingold AL. Bacteriophagebased assays for the rapid detection of rifampicin resistance in Mycobacterium tuberculosis: a meta-analysis. J Infect. 2005;51(3):175-87.

49. Martin A, Portaels F, Palomino JC. Colorimetric redox-indicator methods for the rapid detection of multidrug resistance in Mycobacterium 
tuberculosis: a systematic review and meta-analysis. J Antimicrob Chemother. 2007;59(2):175-83.

50. Blakemore R, Story E, Helb D, Kop J, Banada P, Owens MR, Chakravorty S, Jones $\mathrm{M}$, Alland D. Evaluation of the analytical performance of the Xpert MTB/RIF assay. J Clin Microbiol. 2010;48(7):2495-501.

51. Erali $M$, Wittwer $C T$. High resolution melting analysis for gene scanning. Methods. 2010;50(4):250-61

52. Kalokhe AS, Lee JC, Ray SM, Anderson AM, Nguyen MLT, Wang YF, Shafia M, Metchock B. Multidrug-resistant tuberculosis drug susceptibility and molecular diagnostic testing. Am J Med Sci. 2013;345(2):143-8.

53. van Klingeren B, Dessens-Kroon M, van der Laan T, Kremer K, van Soolingen D. Drug susceptibility testing of Mycobacterium tuberculosis complex by use of a high-throughput, reproducible, absolute concentration method. J Clin Microbiol. 2007;45(8):2662-8.

54. Lawson L, Emenyonu N, Abdurrahman ST, Lawson JO, Uzoewulu GN, Sogaolu OM, Ebisike JN, Parry CM, Yassin MA, Cuevas LE. Comparison of Mycobacterium tuberculosis drug susceptibility using solid and liquid culture in Nigeria. BMC Res Notes. 2013;6(1):1-5.

55. Nguyen TNA, Berre A-L, Bañuls A-L, Nguyen TVA. Molecular diagnosis of drug-resistant tuberculosis; a literature review. Front Microbiol. 2019:10:794.

56. Alcántara R, Fuentes P, Antiparra R, Santos M, Gilman RH, Kirwan DE, Zimic M, Sheen P. MODS-Wayne, a colorimetric adaptation of the MicroscopicObservation Drug Susceptibility (MODS) assay for detection of Mycobacterium tuberculosis pyrazinamide resistance from sputum samples. J Clin Microbiol. 2019;57(2):e01162-e1118.

57. Syre H, Phyu S, Sandven P, Bjorvatn B, Grewal H. Rapid colorimetric method for testing susceptibility of Mycobacterium tuberculosis to isoniazid and rifampin in liquid cultures. J Clin Microbiol. 2003:41(11):5173-7.

58. Evans CA. GeneXpert-a game-changer for tuberculosis control? PLoS Med. 2011:8(7):e1001064

59. Mechal Y, Benaissa E, Benlahlou Y, Bssaibis F, Zegmout A, Chadli M, Malik YS, Touil N, Abid A, Maleb A. Evaluation of GeneXpert MTB/RIF system performances in the diagnosis of extrapulmonary tuberculosis. BMC Infect Dis. 2019;19(1):1-8.

60. Ruesch-Gerdes S, Ismail N, Denkinger C, Gilpin C, Tahirli R, van Deun A, Rigouts L, Hillemann D: REPORT FOR WHO Non-inferiority Evaluation of Nipro NTM+ MDRTB and Hain GenoType MTBDRplus V2 Line Probe Assays. In: Foundation for Innovative New Diagnostics Geneva, Switzerland; 2015.

61. Ling DI, Zwerling AA, Pai M. GenoType MTBDR assays for the diagnosis of multidrug-resistant tuberculosis: a meta-analysis. Eur Respir J. 2008;32(5):1165-74.

62. Wittwer CT. High-resolution DNA melting analysis: advancements and limitations. Hum Mutat. 2009;30(6):857-9.

63. Słomka M, Sobalska-Kwapis M, Wachulec M, Bartosz G, Strapagiel D. High resolution melting (HRM) for high-throughput genotyping - limitations and caveats in practical case studies. Int J Mol Sci. 2017;18(11):2316.

64. Li B-S, Wang X-Y, Ma F-L, Jiang B, Song X-X, Xu A-G. Is high resolution melting analysis (HRMA) accurate for detection of human disease-associated mutations? A meta analysis. PLoS ONE. 2011;6(12):e28078.

65. Caws M, Drobniewski F. Molecular techniques in the diagnosis of Mycobacterium tuberculosis and the detection of drug resistance. Ann NY Acad Sci. 2001;953(1):138-45.

66. Hoek K, van Pittius NG, Moolman-Smook H, Carelse-Tofa K, Jordaan A, Van Der Spuy G, Streicher E, Victor T, Van Helden P, Warren R. Fluorometric assay for testing rifampin susceptibility of Mycobacterium tuberculosis complex. J Clin Microbiol. 2008;46(4):1369-73.

67. Sharma K, Sharma M, Singh S, Modi M, Sharma A, Ray P, Varma S. Realtime PCR followed by high-resolution melting curve analysis: a rapid and pragmatic approach for screening of multidrug-resistant extrapulmonary tuberculosis. Tuberculosis. 2017;106:56-61.

68. Mu J, Liu Z, Zhang C, Wang C, Du W, Lin H, Li K, Song J, Che N, Liu H. Performance of the MeltPro MTB assays in the diagnosis of drug-resistant tuberculosis using formalin-fixed paraffin-embedded tissues. Am J Clin Pathol. 2021;156(1):34-41.

\section{Publisher's Note}

Springer Nature remains neutral with regard to jurisdictional claims in published maps and institutional affiliations.
Ready to submit your research? Choose BMC and benefit from:

- fast, convenient online submission

- thorough peer review by experienced researchers in your field

- rapid publication on acceptance

- support for research data, including large and complex data types

- gold Open Access which fosters wider collaboration and increased citations

- maximum visibility for your research: over $100 \mathrm{M}$ website views per year

At BMC, research is always in progress.

Learn more biomedcentral.com/submissions 